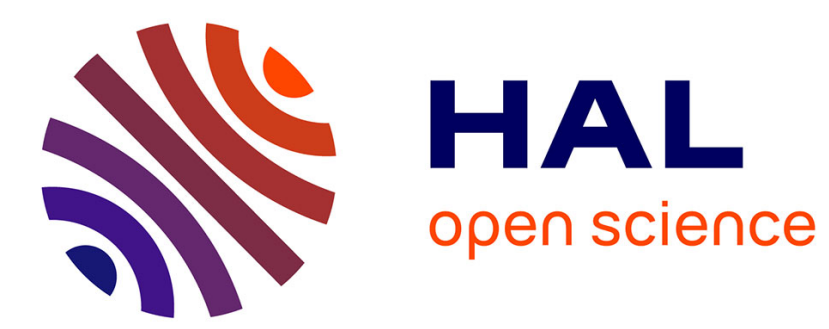

\title{
Corrosion of ceramic matrix composites
}

T. Scanu, Ph. Colomban

\section{- To cite this version:}

T. Scanu, Ph. Colomban. Corrosion of ceramic matrix composites. Journal de Physique IV Proceedings, 1993, 03 (C7), pp.C7-1927-C7-1930. 10.1051/jp4:19937308 . jpa-00251952

\section{HAL Id: jpa-00251952 https://hal.science/jpa-00251952}

Submitted on 1 Jan 1993

HAL is a multi-disciplinary open access archive for the deposit and dissemination of scientific research documents, whether they are published or not. The documents may come from teaching and research institutions in France or abroad, or from public or private research centers.
L'archive ouverte pluridisciplinaire HAL, est destinée au dépôt et à la diffusion de documents scientifiques de niveau recherche, publiés ou non, émanant des établissements d'enseignement et de recherche français ou étrangers, des laboratoires publics ou privés. 


\title{
Corrosion of ceramic matrix composites
}

\author{
T. SCANU and Ph. COLOMBAN
}

ONERA-OM, BP. 72, 92322 Châtillon, France

and

LASIR, CNRS, 2 ne Henri Dunant, 94320 Thiais, France

\begin{abstract}
Air stable ceramic matrix composites are promising for thermostructural applications such as aircraft engine parts. Turbine parts are subject to both sulphuric acid and sodium molten salts corrosion due to sulphate traces in engine fuel and to the $\mathrm{NaCl}$ air content. The chemical stability is a very important criterion but this point has not received much attention to date. We report here a study of acidic and sodium corrosion of various aluminosilicate matrices : LAS matrices ( $\mathrm{Li2} \mathrm{OAl}_{2} \mathrm{O}_{32}-6 \mathrm{SiO}_{2}, \mathrm{nP} 2 \mathrm{O5}$ ) in the amorphous, $\beta$ eucryptite and $\beta$ spodumene forms, BAS matrix (BaOAl2O32SiO2) in the form of monoclinic and hexagonal celsian, NASICON matrix (NazZr2Si2PO12) and mullite matrix. Microstructure damages and ion exchange have been analysed by X-ray diffraction, IR absorption, scanning electron microscopy and Raman microprobe. Drastic corrosion is observed for $\beta$ spodumene containing composites with the formation of strong hydrogen bond or with the cell expansion due to $\mathrm{Li} / \mathrm{Na}^{+}$exchange. Medium acidic attack occurs for glassy LAS, $\beta$ eucryptite, BAS and NASICON matrix composites. On the other hand, $\beta$ eucryptite, NASICON and monoclinic celsian resist to alkaline melts. Mullite matrix composites are never corroded.
\end{abstract}

\section{INTRODUCTION}

The matrix of ceramic matrix composites is usually selected in reference with the melting point and by the following criteria : high Young's modul us, low thermal expansion. An important criterion to obtain high mechanical properties is that the thermal dilatation of the matrix is lower or at least equal to that of the fiber, in order to avoid the crack formation during the elaboration and the thermal cycling of the composite. Matrix compositions are thus chosen among loose-packed frameworks. Loose-packed framework promotes also ionic conductivity and ion exchange. Ion exchange is relatively rare in dense solids but it is common in loose-packed structures and this phenomenon is intimately related to the (superlionic conductivity $(1,2)$. Loose-packed frameworks are also needed for low thermal expansion : the rotation of molecular bricks (e.g. SiO4, AlO4, PO4, AlO6, ...) counterbalances the bond length increase with temperature, the resulting unit-cell parameters and the unit-cell volume being thus stable or even decreased, anisotropically, over a large temperature range. On the other hand, dense structures exhibit always high thermal expansion coefficients. In structures where the host framework is sufficiently loosely packed alkali or earth-alkali ions diffuse, easily $(1,3)$. Glasses are usually poorer ion exchangers and poorer ionic conductors than crystalline phases of similar composition and structure. Ion exchange induces change of the unit-cell parameters, directly from the exchange or indirectly with the phase transitions resulting from the back to the stable phases. A dilatation is generally associated to the formation of cracks and then to a drastic lowering of the mechanical properties, whereas the contraction may preserve the mechanical properties $(4,5)$. Furthermore, the ion exchanged material can be metastable and, for example, hydrogen substituted structures have a lower thermal stability (2). We report here a study of the sulphuric acid and sodium nitrate corrosion of various matrices. The ion exchange and the 


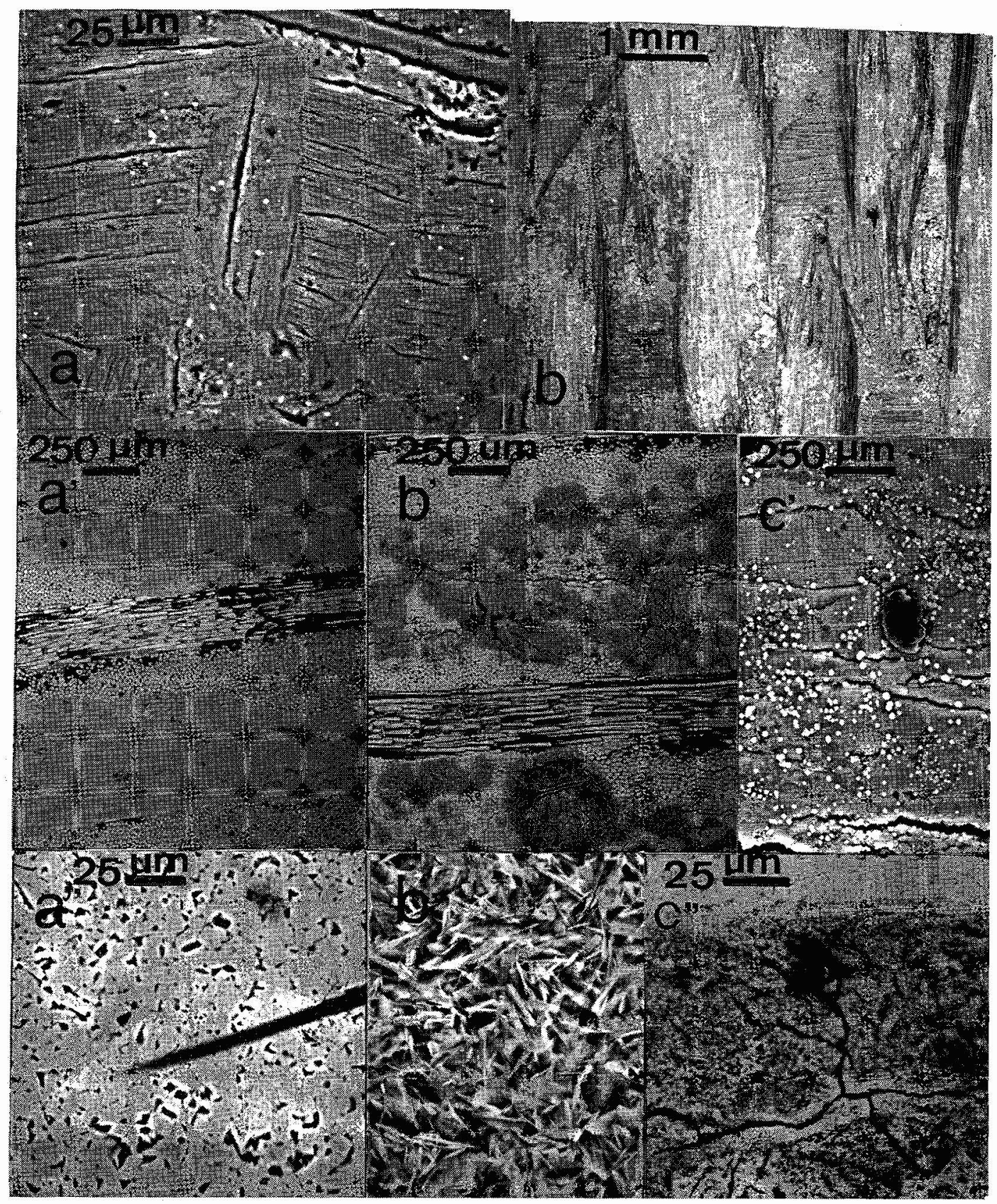

Fig. 1 : Photomicrographs of various matrices of ceramic matrix composites before (a', a") and after acidic ( $\left.a, b^{\prime}, b^{\prime \prime}, c^{\prime \prime}\right)$ or alkaline (b, $\left.c^{\prime}\right)$ corrosion : $a, b, \beta$ spodumene (keatite) LAS matrix ; $a^{\prime}, b^{\prime}, c^{\prime}$ amorphous $P$ containing LAS matrix ; $a^{\prime \prime}, c^{\prime \prime}$, BAS matrix ; $c$ " NASICON matrix (backscattered electron mode). 
corresponding microstructure changes have been analysed by X-ray diffraction, scanning electron microscopy, chemical analysis and vibrational spectra.

\section{EXPERIMENTAL}

The fabrication of 20 SiC Nicalon NLM202 woven fabrics reinforced composites was previously reported : two routes have been used, a conventional melting route for "crystalline" LAS matrix (6) and a new sol-gel route for amorphous LAS, monoclinic (celsian) BAS, NASICON and mullite matrices (7). Alkaline and acid corrosion were performed by immersion of polished samples in molten nitrate or in boiling concentrated sulfuric acid, for times comprised between $5 \mathrm{~min}$ and 10 hours. Crushed samples $(\sim 0.5 \mathrm{~mm})$ are used for Li loss measurements.

\section{RESULTS AND DISCUSSION}

LAS Matrices. The nominal compositions of our $\beta$ eucryptite and $\beta$ spodumene ("keatite") matrices are close to $\mathrm{LiAlSi}_{2} \mathrm{O}_{6}$ and $\mathrm{LiAlSi}_{3} \mathrm{O}_{8}$, respectively. After acidic attack, we observe a drastic contraction $(>8 \%)$ of $\beta$ spodumene $c$ parameter whereas the changes for $\beta$ eucryptite phase are moderate, according to the literature $(8,9)$. Although immersion of $\beta$ eucryptite in molten NaNO3 induces no change, a crushing of the $\beta$ spodumene matrix is observed, according to previous works $(10,11)$ : the $c$ parameter increases from 9.04 to $9.14 \mathrm{~A}$. Fig. 1 shows typical photomicrographs of $\beta$ spodumene matrix-SiC fiber composites. After contact with boiling acid, polished samples exhibit parallel cracks which give evidence of the large size of $\beta$ spodumene crystals. The cracks result from the contraction due to the formation of strong hydrogen bonds between $\mathrm{Si}_{(\mathrm{Al}) \mathrm{O}}$ tetrahedra (12). The cracks reveal the dendritic crystallization around $\mathrm{SiC}$ fibers. With the $\mathrm{Li}^{+} / \mathrm{Na}^{+}$exchange, the large expansion of $c$ parameter ( 10\%) crushed the matrix. Figs. 1a', $b^{\prime}, c^{\prime}$ show changes observed for glassy, $P$ containing LAS matrix. After acid or alkaline attacks we observe a network of irregular cracks. Some cracks are roughly parallel to the $\mathrm{SiC}$ woven fabric sheets which reveals the stress due to the fiber/matrix dilatation mismatch. This indicates a contraction of the amorphous structure after both $\mathrm{H}^{+}$or $\mathrm{Na}^{+}$exchange. As shown on Fig. 2 , the $\mathrm{Li}^{+} / \mathrm{H}^{+}$exchange is slower in amorphous LAS (here $P$ free) than in $\beta$ eucryptite or $\beta$ spodumene phases. The unexchangeable $\mathrm{Li}^{+}$ions of our $\beta$ eucryptite sample are due to the presence of an amorphous second phase.

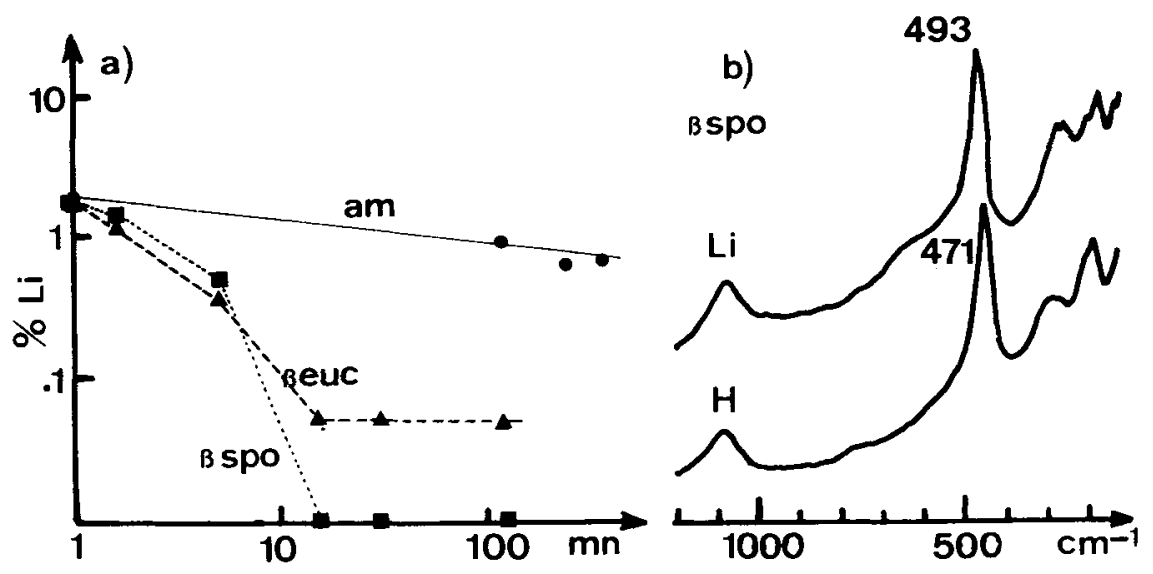

Fig. 2 : a) Evolution of the $\mathrm{Li}$ content $(\%$, in weight) versus leaching time in boiling pure $\mathrm{H}_{2} \mathrm{SO}_{4}$ for amorphous LAS (am), $\beta$ eucryptite LAS (Euc) and $\beta$ spodumene LAS (spo). Comparison of Raman spectra of $\beta$ spodumene LAS/SiC composite recorded before (up) or after (down) acidic corrosion is given in $b$. 
As shown on Fig. $2 \mathrm{~b}$, the $\mathrm{Li}^{+} / \mathrm{H}^{+}$exchange can be controlled by Raman microspectroscopy using the frequency shift of the main band, e.g. from $493 \mathrm{~cm}^{-1}$ in Li $\beta$ spodumene to $471 \mathrm{~cm}^{-1}$ in H-form (13).

BAS matrix. Whereas no attack is visible for monoclinic celsian/SiC composites immersed in molten $\mathrm{NaNO}_{3}$ for a few hours, a partial dissolution is observed after contact with boiling $\mathrm{H}_{2} \mathrm{SO}_{4}$ (Fig. 1b") for both hexagonal and monoclinic celsians.

NASICON matrix. This matrix is stable in molten NaNO3. On the other hand, sulphuric acid induces the cracking of the matrix according to a possible ion exchange (14) (Fig. 1c").

Mullite matrix. No change has been observed.

\section{CONCLUSION}

The following chemical stability scales can be proposed

. in acidic atmosphere : mullite $\gg>B A S$, amorphous LAS $>$ NASICON, $\beta$ eucryptite $>\beta$ spodumene

. in presence of molten alkali salts : mullite, $\beta$ eucryptite, NASICON $>B A S \gg \gg \beta$ spodumene.

The $\beta$ spodumene phase usually selected according to mechanical criteria is thus the phase to be prohibed from the corrosion point of view. The use of refractory, chemically stable matrices (e.g. mullite) reinforced by nano or microprecipitates appears to be a better solution whatever a higher dilatation coefficient (15).

\section{REFERENCES}

[1] KUMMER J.T., Progress in Solid State Chem. 7 (1972) 141.

[2] COLOMBAN Ph., ed., Proton Conductors, Cambridge University Press, Cambridge, (1992).

[3] BOILOT J.P., LEE M.R., COLOMBAN Ph., COLlin G. and COMES R., J. Phys. Chem. Solids 47 (1986) 693.

[4] Lenfant P., PlaS D., RUfFo M. and COLOMBAN Ph., Mat. Res. Bull. 15 (1980) 1817.

[5] NICHOLSON P.S., in ref. 2, Ch. 33, p. 499-510.

[6] PARLIER M., RITTI M.H., STOHR J.F. and VIGNESAULT S., Proc. ICAS 90, Stockholm, Sept. 9-14 (1990).

[7] ColomBAN Ph., in Proc. Bemes Journées Nationales sur les Composites, Palaiseau, Nov. 16-18 1992, ALLIX O., FAVRE J.P. and LADEVEZE P., eds., AMAC, Paris (1992) 73.

[8] VOGT T., PAULUS H., FUESS H. and MULLER G., Z. Kristallogr. 190 (1990) 7.

[9] PAUlus H., FUeSS H., MUller G. and voGT T., Neues Jahr. Mineral, Monatsh. 115 (1990) 232.

[10] GROSSMAN D.G. and LANNING J.G., Ceram Bull. 56 (1977) 974.

[11] MULLER G., HOFFMAN M. and NEEF R., J. Mater. Sci. 23 (1988) 1779.

[12] COLOMBAN Ph., J. Mol. Struct. 270 (1992) 407.

[13] SCANU T., GUGLIELMI J. and COLOMBAN Ph., Solid State Ionics, submitted.

[14] CLEARFIELD A., in ref. 2, Ch. 15, p. 224-237.

[15] MOUCHON E. and COLOMBAN Ph., Proc. EACM-High Temperature CMC, ECCM-6, Bordeaux, Sept. 20-24 1993, R. NASLAIN, ed. 